\title{
Promises, promises: Can the female offender strategy deliver?
}

\section{Natalie Booth}

De Montfort University, UK

\section{Isla Masson}

University of Leicester, UK

\section{Lucy Baldwin}

De Montfort University, UK

\section{Abstract}

Following a number of postponements, the long awaited and much needed female offender strategy for England and Wales was finally published in June 2018. The strategy reflects the strong agreement across the sector of the need for a 'distinct' or 'gender-specific' approach to respond to the vulnerabilities of women in the Criminal Justice System (CJS). Despite this, the strategy lacks clarity and offers little assurance that the direction taken will result in actual change and positive reform. It is vital that the government's implementation of the female offender strategy provides and demonstrates a genuine commitment to appropriate provision for females in the CJS through ring-fenced permanent funding as well as top-down accountability.

\section{Keywords}

female offender strategy, women in the criminal justice system, penal policy, genderspecific, female prisoners

\section{Corresponding Author:}

Natalie Booth, De Montfort University, School of Humanities, Division of Community and Criminal Justice, Hawthorn Building, Leicester LE1 9BH, UK.

Email: natalie.booth@dmu.ac.uk 


\section{Looking to evidence: A shared vision for reform}

There can be few topics that have been so exhaustively researched to such little practical effect as the plight of women in the criminal justice system. (Corston, 2007: 16)

As this quotation from Baroness Jean Corston indicates, there is a long standing and rich body of literature citing similar and overlying concerns, struggles and remedies for women in the criminal justice system, which has come to little or no avail (Carlen, 1985, 2002; Gelsthorpe and Morris, 2002; Worrall and Gelsthorpe, 2009). Unfortunately, these sentiments shared over a decade ago are still as relevant today (Women in Prison (WiP), 2017). Many have also argued that the overuse of short sentences for non-violent female offenders, be that on sentence or remand, serves little purpose, especially when removing women from the community land, importantly, often from their children) for a short period of time (Baldwin and Epstein, 2017; Masson, 2014, forthcoming). This has continued despite repeated calls for better use of 'alternatives', for example, most recently the current Secretary of State for Justice, David Gauke, acknowledged how 'diversion, restorative justice and community sentences continue to be underused' (The Times, May 2018).

Women constitute a minority group in the CJS, representing just 5 per cent of the prison population in England and Wales (Ministry of Justice (MoJ), 2018a), but it is widely agreed that they enter the CJS with multiple and complex needs (Corston, 2007; Gelsthorpe et al., 2007; Hedderman et al., 2008). This is often owing to the adversities they have experienced before custody, characterised by poor education, unstable housing, poverty, mental health and substance abuse (Burgess and Flynn, 2013; Prison Reform Trust (PRT), 2017a; Williams et al., 2012). Many also report having been victims of both physical and sexual abuse (PRT, 2017b). Additionally, many live with, or are primary caregivers of, children prior to their imprisonment (Baldwin, 2015; Booth, 2017a, 2017b; Caddle and Crisp, 1997; Masson, 2014, forthcoming; PRT, 2015). It is these vulnerabilities that accompany women into the CJS that led Corston (2007: 16) to articulate that 'equal treatment of men and women does not result in equal outcomes'. Frustrations over a clear strategy stem partly from the embarrassment of riches with regard to recommendations for better approaches to address the level of unmet need for female offenders (for example, Baldwin, 2015; Carlen, 1985; Corston, 2007; PRT, 2017a; WiP, 2017; Worrall and Gelsthorpe, 2009). For over 40 years (with a particular momentum in the last decade) we have seen calls for reform and recommendations coming from all corners of the sector (i.e. academe, international legislation, reform organisations and charities), as well as political parties and agencies.

\section{Looking to the government: Promises and postponements}

Echoing the evidence, successive governments have repeatedly drawn upon the concept of a 'distinct approach' for women (House of Commons, 2017; House of Commons Justice Committee, 2013; MoJ, 2012), acknowledging that women have different vulnerabilities and needs. Despite this repeated rhetoric, there has been 
very little change in relation to the delivery of policy and practice for women offenders. Unfortunately, when change has come, it has not always been positive. For instance, concerns voiced by academics and practitioners about the potential for increased harm in relation to female law breakers due to Transforming Rehabilitation (TR) have, sadly, become a reality (Crook, 2016; Annison and Brayford, 2015; House of Commons Justice Committee, 2013; PRT, 2013). The number of women under supervision recalled to prison has more than doubled post TR, with 1458 women recalled in the year leading up to June 2017 (PRT, 2017a). The landscape for many women post TR is bleak (Trebilcock and Dockley, 2015) and remains uncertain in light of the recently announced reorganisation of probation services (MoJ, 2018c). The reorganisation is clear recognition that 'fundamental reform is needed' (Webster, 2018). Evidence also suggests that women's centres have the ability to support women involved in the CJS in a more holistic way than other sentences (Howard League for Penal Reform, 2016; Annison et al., 2018). However, as a result of TR 'the majority have been hampered by instability due to short-term funding, often relying on a patchwork of support from the Ministry of Justice, local probation, charities and health' (All Party Parliamentary Group, 2016: 2).

We acknowledge that there has been positive change in the approach taken by some justice agencies, such as HM Inspectorate of Prisons (HMIP, 2014), who have created gender-specific 'expectations' for the treatment of women in prison. However, due to the absence of an overarching strategic vision it is uncertain how elsewhere this 'distinct approach' is integrated into practical solutions and support for women. This is especially the case in light of unstable budgets throughout the CJS (Ford, 2017). In addition, despite multi-party support for the vast majority of the 43 recommendations in Corston's (2007) seminal review, WiP (2017: 27) recently concluded that 'we have seen a stagnation and loss of momentum in fully implementing the Corston report's recommendations in recent years'. The Farmer Review (2017) correctly identifies the importance of positive developments in relation to the role of the family in rehabilitation, and the need for criminal justice agencies to support families in this role. However, it is important to note that the Farmer Review was unapologetically concerned with male law breakers and ignores how connotations of family have different implications for women.

The timeline in Figure 1 demonstrates the promises and postponements leading up to the publication of the female offender strategy as well as the variable political and social context in Britain. The reduced attention on women affected by the CJS may have been a result of the political instability that followed both the Brexit referendum and the snap general election. Although we welcome the introduction of a women's lead in Her Majesty's Prison and Probation Service (HMPPS), in this same short period there were three different minsters assuming the role of Secretary of State for Justice, which has inevitably inhibited consistency and a continued vision. Progress cannot be made when those driving the strategy keep changing. There was indication that some of the delays in publication of the strategy were owing to funding issues that led to an instruction for the document to be 'rewritten' (The Guardian, 2018). This might suggest some backtracking or U-turning of the 


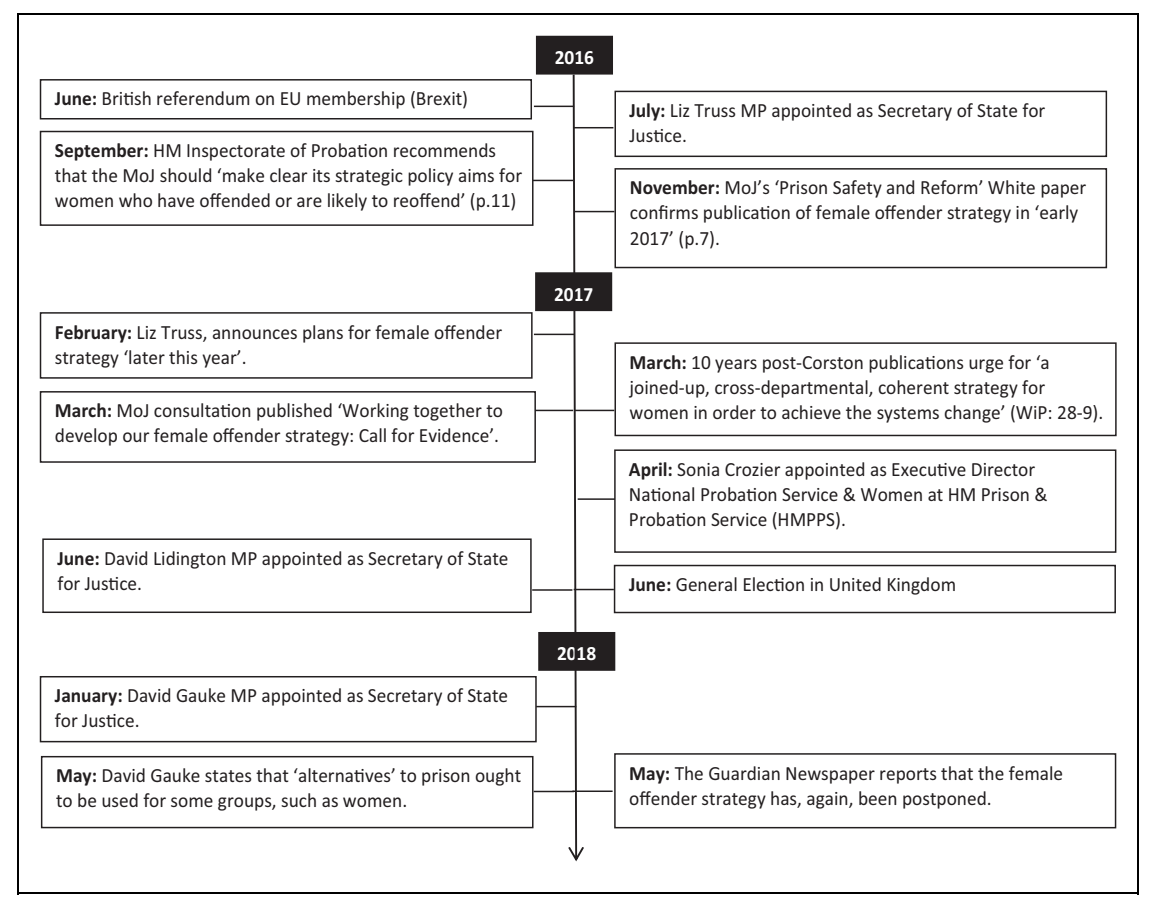

Figure 1. Timeline leading up to the publication of the Female Offender Strategy (2016-2018).

initial promises or plans that were put forward. Taken together, these events may have impeded the momentum required to release the finalised female offender strategy that was so desperately needed by women affected by the CJS. Consistent political commitment to the development, implementation and evaluation of the reforms is vital for the success of the strategy.

\section{Looking to the future: Can the female offender strategy deliver?}

The 'Female Offender Strategy' (MoJ, 2018b) published in June 2018 appears to consolidate many of the recommendations put forward in the plethora of evidence available on women in CJS. Demonstrating this, the strategic priorities seek to reduce the number of women in contact with the CJS, and specifically in prison, and to improve prison conditions. It acknowledges that a whole system, multi-agency approach is necessary to bring about change and suggests that this is achievable through locally-led, partnership-focused and evidence-based working. The strategy outlines plans for a further Farmer Review focusing on the family ties for women, and the replacement of the Prison Service Order 4800 (which sets out the genderinformed standards for working with women prisoners) with a Women's Policy Framework that will provide guidance for working with women throughout the CJS. 
To fulfil their commitment, the strategy promises to invest $£ 5$ million of crossgovernment funding, develop 'residential women centres' and reduce the number of women serving short sentences.

However, the strategy ought to have clearly outlined the specific pathways, resources and changes to lead to improvements in the current system. In reviewing the strategy, we have identified a number of areas that are cause for concern. Firstly, the tone and language used in certain instances within the strategy is disappointing. For example, the concept of 'productive citizens' (MoJ, 2018b: 334) reinforces negative images of women, providing a smoke screen to the wider social context, whilst instead favouring the responsibilisation of the individual. There is also a risk of history repeating itself with 'women-centred' and 'enlightened' ideologies 'fail[ing] to deliver equality of justice for women' (Worrall and Gelsthorpe, 2009: 334). Meanwhile, poorly evidenced assumptions from the male estate regarding intergenerational offending are being regurgitated with little consideration to the application to maternal incarceration. The authors also have concerns that the strategy is vague, for example not providing the mechanics for how it will be operationalised, with ambiguous proposals that strive to be both 'locally-led' and 'partnership-focused' at a national level (MoJ, 2018b: 7). It provides sound bites of optimism that are unsubstantiated by facts and figures. By way of illustration, although there are plans to develop residential women's centres in at least five sites across England and Wales, there is no indication of the economic provision to support such ambitions.

One key way to have ensured women would be at the centre of criminal justice policy was to introduce gender-specific sentencing guidelines to better enable women's diversion from prison and, where appropriate, from the CJS altogether (Baldwin and Epstein, 2017). This separation would have mirrored that of the youth justice system and facilitated gender appropriate punishments. However, there was a missed opportunity in the strategy where there appears to be an abdication of responsibility with regard to gender-specific guidelines, alongside a reluctance to direct the judiciary to alter their sentencing practices. Another potentially less transformative approach would have been to have adopted best practice from Scotland and have a presumption against short prison sentences (The Criminal Justice and Licensing (Scotland) Act, 2010). This would have increased the use of less financially and emotionally expensive community sentences, suspended sentences and use of women's centres. Although promising that they are exploring innovative practice from Scotland (for example Scotland's 218 Centre), it is disappointing that the strategy has failed to definitively adopt such models or a presumption against short sentences. For critics who maintain that 'alternatives' are not punitive enough, it is suggested that concerns may be quashed by the use of potentially emotionally draining and challenging restorative justice (R) conferences (Masson and Osterman, 2017). We were therefore very surprised to see no mention of restorative justice in the strategy given previous financial investment and ongoing rhetoric which supports this approach, including a recent statement by David Gauke (The Times, May 2018). 
However, there were aspects of the strategy that we wholeheartedly embrace. We are thrilled with the current proposal to shelve the development of new women's prisons in favour of community-based solutions. We sincerely hope that conversations do not return to this matter with any potential change in political or financial climate. We were also pleased to see the proposed revision and expansion of Prison Service Order (PSO) 4800 (National Offender Management Service (NOMS), 2008) with a 'Women's Policy Framework'. This ought to inform the conditions and treatment of the prison environment as well as the wider criminal justice system. We expect this framework will also show commitment to international guidelines (UN Bangkok Rules, 2010), and the growing evidence-base to ensure that operations in practice are concurrent with the vast knowledge which outlines the challenges faced by women in the CJS (Baldwin, 2018; Booth, 2017a, 2018; Crewe et al., 2018; Masson, 2014, forthcoming). Furthermore, it is encouraging to see the promise of a further Farmer Review focusing on females and their families affected by the criminal justice system. Within this, we hope to see 'through the gate' recognition and support for families affected by maternal imprisonment, with specific guidance and support in relation to rebuilding and reuniting families factored in to post-release supervision (Baldwin, 2017; Masson, 2014, forthcoming). However, we urge consideration of the diverse forms of 'family' alongside women's lived experience and their histories that may feature abuse and dysfunctional relationships.

There are many promises within the strategy but we are acutely aware that positive change can only be delivered through ongoing financial resources. Therefore, we were utterly dismayed that the original $£ 30$ million (The Guardian, 2018) that was identified for the Female Offender Strategy has been slashed to $£ 5$ million, rendering the many promises within the strategy impossible to deliver. It is especially disconcerting to observe that some of the financial resources needed to make this strategy work are subject to the eventual closure of some women's prisons. This is problematic because it is unpredictable and fails those currently in the system. Any assurances within the strategy would be more credible through permanent, ring-fenced funding and resource-provision. Initiatives, like women's centres and 'through the gate' support, need the space and support to thrive; this is not possible with unstable, patchwork provision.

In conclusion, many women who end up in prison do so after experiencing a number of vulnerabilities beforehand. There is a plethora of research that suggests that most female offenders can be diverted from prison and dealt with in the community with more positive outcomes for all involved. We are pleased that the Female Offender Strategy has committed to shelving the development of new women's prisons, to a revised gender-specific prison (and CJS) directive, as well as the women-specific Farmer Review. However, we have serious concerns that the strategy does not support gender-specific sentencing guidelines, a presumption against short sentences, or pay attention the potential benefits of restorative justice. We also identified issues concerning the tone, language and vagueness of the strategy and the implications of this for achieving positive change with any immediacy. Fundamentally underscoring the strategy we identified a significant issue with the finances 
that are supposed to enable the proposed changes. Women in the CJS deserve confirmation of informed action, ring-fenced, committed and permanent funding, and top-down accountability. Without this, the Female Offender Strategy will be unable to deliver any of the promises and they will become broken promises.

\section{Declaration of Conflicting Interests}

The author(s) declared no potential conflicts of interest with respect to the research, authorship, and/or publication of this article.

\section{Funding}

The author(s) received no financial support for the research, authorship, and/or publication of this article.

\section{References}

All Party Parliamentary Group on Women in the Penal System (2016) Is This the End of Women's Centres? London: Howard League for Penal Reform.

Annison J and Brayford J (2015) Corston and beyond. In: Annison J, Brayford J and Deering J (eds) Women and Criminal Justice: From the Corston Report to Transforming Rehabilitation. Bristol: Policy Press.

Annison J, Byng R and Quinn C (2018) Women offenders: Promoting a holistic approach and continuity of care across criminal justice and health interventions. Criminology and Criminal Justice. DOI: 10.1177/1748895818773805.

Baldwin L (2015) Mothering Justice: Working with Mothers in Criminal and Social Justice Settings. Sherfield on Loddon: Waterside Press.

Baldwin L (2017) Tainted love: The impact of prison on maternal identity, explored by post prison reflections. Prison Service Journal 233: 28-34

Baldwin L (2018) Motherhood disrupted: Reflections of post-prison mothers. Emotion Space and Society (Special Edition: 'Maternal Geographies') 26: 49-56.

Baldwin L and Epstein R (2017) Short but not sweet: A study of the impact of short custodial sentences on mothers and their children Available at: https://www.dora.dmu.ac.uk/ xmlui/handle/2086/14301 (accessed 1 June 2018).

Booth N (2017a) Maternal imprisonment: A family sentence. In: Hudson J, Needham C and Heins E (eds) Social Policy Review 29: Analysis and Debate in Social Policy. Bristol: The Policy Press and Social Policy Association.

Booth N (2017b) Prison and the family: an exploration of maternal imprisonment from a family-centred perspective. PhD Thesis, University of Bath, UK.

Booth $N$ (2018) Maintaining family ties: The disparities between policy and practice following maternal imprisonment in England and Wales. In: Gordon L (ed.) Contemporary Research and Analysis on the Children of Prisoners: Invisible Children. Cambridge: Cambridge Publishers Ltd.

Burgess A and Flynn C (2013) Supporting imprisoned mothers and their children: A call for evidence. Probation Journal 60(1): 73-81.

Caddle D and Crisp D (1997) Imprisoned Women and Mothers: Research Study 162. London: Home Office. 
Carlen P (1985) Criminal Women. Cambridge: Polity Press.

Carlen P (2002) Women and Punishment: The Struggle for Justice. Cullompton: Willan.

Corston J (2007) The Corston Report: A Report by Baroness Jean Corston of a Review of Women with Particular Vulnerabilities in the Criminal Justice System. London: Home Office.

Crewe B, Hulley S and Wright S (2017) The gendered pains of life imprisonment. British Journal of Criminology 57: 1359-1378.

Crook F (2016) Transforming Rehabilitation is having a disastrous impact on women. Howard League for Penal Reform Blog. Available at: https://howardleague.org/blog/ transforming-rehabilitation-is-having-a-disastrous-impact-on-women/ laccessed 15 September 2018).

Lord Farmer (2017) The importance of strengthening prisoners' family ties to prevent reoffending and reduce intergenerational. Available at: https://assets.publishing. service.gov.uk/government/uploads/system/uploads/attachment_data/file/642244/ farmer-review-report.pdf (accessed 1 September 2017).

Ford T (2017) Trends in Criminal Justice Spending, Staffing and Populations. London: Centre of Crime and Justice Studies.

Gelsthorpe L and Morris A (2002) Women's imprisonment in England and Wales: A penal paradox. Criminal Justice 2(3): 277-301.

Gelsthorpe L, Sharpe G and Roberts J (2007) Provision for Women Offenders in the Community. London: The Fawcett Society.

Hedderman C, Palmer E and Hollin C (2008) Implementing Services for Women Offenders and Those 'At Risk' of Offending. London: Ministry of Justice.

HM Inspectorate of Probation (HMIP) (2014) Expectations: Criteria for assessing the treatment of and conditions for women in prison. Available at: https://www. justiceinspectorates.gov.uk/hmiprisons/wp-content/uploads/sites/4/2014/02/finalwomens-expectation_web-09-14-2.pdf (accessed 1 June 2018).

HM Inspectorate of Probation (HMIP) (2016) A thematic inspection of the provision and quality of services in the community for women who offend. Available at: https:// www.justiceinspectorates.gov.uk/hmiprobation/wp-content/uploads/sites/5/2016/ 09/A-thematic-inspection-of-the-provision-and-quality-of-services-in-the-community-forwomen-who-offend.pdf (accessed 1 June 2018).

House of Commons Justice Committee (2013) Women Offenders: After the Corston Report. Second Report of Session 2013-14. London: The Stationary Office Ltd.

House of Commons (2017) Women Released from Prison. Debate Pack. London: House of Commons Library Number CDP-2017-0181.

Howard League of Penal Reform (2016) Ten years after The Corston Report, is this the end of successful women's centres? Available at: https://howardleague.org/news/ isthistheendofwomenscentres/ (accessed 3 June 2018).

Inside Time (2017) The secret criminologist. Available at: https://insidetime.org/the-secretcriminologist-5/ (accessed 3 June 2018).

Masson I (2014) The long-term impact of short periods of imprisonment on mothers. PhD thesis, King's College London, UK.

Masson I (forthcoming) Incarcerating Motherhood: The Enduring Harms of First Short Periods of Imprisonment on Mothers. Oxford: Routledge. 
Masson I and Österman L (2017) Working with female offenders in restorative justice frameworks: Effective and ethical practice. Probation Journal 64(4): 354-371.

Ministry of Justice (MoJ) (2012) A Distinct Approach: A Guide to Working with Women Offenders. London: Ministry of Justice.

Ministry of Justice (MoJ) (2016) Prison Safety and Reform. London: Ministry of Justice.

Ministry of Justice (MoJ) (2018a) Prison population figures: 2018. Population Bulletin: Weekly, 20 July. Available at: https://www.gov.uk/government/statistics/prisonpopulation-figures-2018 (accessed 2 August 2018).

Ministry of Justice (MoJ) (2018b) Female Offender Strategy. London: HMSO.

Ministry of Justice (MoJ) (2018c) Justice Secretary outlines future vision for probation. Available at: https://www.gov.uk/government/news/justice-secretary-outlines-futurevision-for-probation (accessed 28 July 2018).

Moore L, Scraton P and Wahidin A (2017) Women's Imprisonment and the Case for Abolition: Critical Reflections on the Corston Ten Years On. London: Routledge.

National Offender Management Service (NOMS) (2008) Prison Service Order (PSO) 4800.

Prison Reform Trust (2013) Prison Reform Trust briefing on the Offender Rehabilitation Bill, House of Commons Second Reading, 11 November 2013. Available at: http://www. prisonreformtrust.org.uk/Portals/0/Documents/Prison\%20Reform $\% 20$ Trust $\% 20$ Briefing $\% 20$ Offender\%20\%20Rehabilitation $\% 20 \mathrm{Bill} \% 20 \mathrm{HoC} \% 202$ nd $\% 2$ Reading \%2011 Nov13.pdf (accessed 20 June 2017).

Prison Reform Trust (PRT) (2015) Sentencing of mothers: Improving the sentencing process and outcomes for women with dependent children. Available at: http://www. prisonreformtrust.org.uk/Portals/0/Documents/sentencing_mothers.pdf /accessed 13 June 2018).

Prison Reform Trust (PRT) (2017a) Bromley briefings prison Factfile, Autumn 2017. Available at: http://www.prisonreformtrust.org.uk/Portals/0/Documents/Bromley\%20Briefings/ Autumn\%202017\%20factfile.pdf (accessed 13 June 2018).

Prison Reform Trust (PRT) (2017b) There's a reason we're in trouble: Domestic abuse as a driver to women's offending. Available at: http://www.prisonreformtrust.org.uk/Portals/ 0/Documents/Bromley\%20Briefings/Autumn\%202017\%20factfile.pdf laccessed 14 June 2018).

The Criminal Justice and Licensing (Scotland) Act (2010) London: HMSO.

The Guardian (2018) MoJ postpones plans to reduce female prison population. Strategy to cut numbers being jailed for non-violent offences was to be launched this month. Available at: https://www.theguardian.com/society/2018/may/02/moj-postponesplans-on-reducing-female-prison-population-strategy-non-violent-offences laccessed 2 May 2018).

The Times (2018) David Gauke interview: 'It's the carrot and stick: Prisoners need to have a sense of purpose'. Available at: https://www.thetimes.co.uk/article/david-gaukeinterview-it-s-the-carrot-and-stick-prisoners-need-to-have-a-sense-of-purpose-2mp5qt0kx (accessed 01 June 2018).

Trebilcock J and Dockley A (2015) 'A very high price to pay?': Transforming rehabilitation and short prison sentences for women. In: Brayford J, Annison J and Deering J (eds) Women and Criminal Justice: From the Corston Report to Transforming Rehabilitation. London: Policy Press. 
United Nations (2010) The United Nations Bangkok Rules on women offenders and prisoners: Short guide. Available at: https://www.penalreform.org/wp-content/ uploads/2013/07/PRI-Short-Guide-Bangkok-Rules-2013-Web-Final.pdf /accessed 11 October 2018).

Webster R (2018) The end of Transforming Rehabilitation. Available at: http://www. russellwebster.com/endtr/ (accessed 1 August 2018).

Williams K, Papadopoulou V and Booth N (2012) Prisoners' childhood and family backgrounds. Results from Surveying Prisoner Crime Reduction (SPCR) longitudinal cohort study of prisoners. Ministry of Justice Research Series 4/12.

Women in Prison (WiP) (2017) Corston + 10: The Corston Report 10 years on. How far have we come on the road to reform for women affected by the criminal justice system? Available at: http://www.womeninprison.org.uk/perch/resources/corston-report-10years-on.pdf (accessed 1 June 2018).

Worrall A and Gelsthorpe L (2009) 'What works' with women offenders: The past 30 years. Probation Journal 56(4): 329-345. 